\title{
線溶酵素活性測定法の自動化の試み
}

椙 江 勇* 丹 下 由紀子*
伊 藤 要 子* 山本 紘 靖*

\section{The studies of auto-analyzer system for fibrinolytic activity of plasma by means of chromogenic substrate}

\author{
Isamu SUGIE*, Yukiko TANGE*, Yoko ITO* \\ and Hiroyasu YAMAMOTO*
}

Key words : auto-analyzer, chromogenic substrate, kinetics, end point, fibrinolytic activity of plasma

With the use of chromogenic substrate (S-2251), rate assay (kinetics) and end point assay of enzyme activity of human plasmin and human plasminogen, euglobulin and plasma by SK or UK were studied using by auto-analyzer (HitachiCo., type-703).

The chromogenic substrate was enzymatically good substrate for plasmin and $\mathrm{K}_{\mathrm{m}}$ value of plasmin was $7.6 \times 10^{-4} \mathrm{mM}$. . When plasma was activated by $\mathrm{SK}$, the highest value of kinetics was seen at initial time but UK had lag time. From these results, it is suggested that even with the use of small dose of substrate $(0.1 \mathrm{uM})$, auto-analyzer could be applied to measure fibrinolytic activity of human plasma $(0.05 \mathrm{ml})$ activated by SK (500 U) on kinetics.

\section{はじめに}

線溶酵素の测定法について，われわれはこれ まで ELT 装置の開発やフィブリン平板法にお ける線溶諸因子の判別測定法を発表してき $た^{1 \sim 4)}$. しかし, 近年線溶酵素の役割が単に出 血機序にとどまらず，各種疾患時や生理的にも その動態が注目されるとともに各分野で線溶醉 素の測定が要求されるようになった.

われわれはこの線溶酵素測定の自動分析化の ため当初 fibrin 基質を微細粒子として測定を試 みたが, 安定した粒子の作成および比濁法に難 点があり中断した. しかし最近 Kabi 社におい て合成ペプタイドと発色団による chromogenic
Substrate (C-Sub.) が開発された. このCSub. は線溶凝固系の各酵素に 特異的な基質が 開発されており，今回は Plasmin に特異的な S-2251 を用い, 自動分析機として酵素反応速 度測定装置 (日立 703 型) を用いて，血漿 Plasmin 活性の測定が可能であるか，さらにそ の測定法の妥当性について検討した.

\section{I. 測 定 方 法}

1. 反応ライン 基本動作としてあらかじめ 恒温水槽 $\left(37^{\circ} \mathrm{C}\right)$ 亿配列されている小試験管に buffer (0.05M Tris $\mathrm{pH} 7.4) 1.4 \mathrm{~m} l$ と試料 $0.05 \mathrm{~m} l$ をサンプリングノズルで注入し，15分 後にディスペンサーで基質 (S-2251) $0.1 \mathrm{~m} l$ を

* 愛知医科大学第一生理 [广 $480-11$ 愛知県愛知郡長久手町大字岩作字倠又21], Dept. of Physiology, Aichi Medical University, Aichi, Japan. 
注入，攪拌， 1 分後に測光により反応 速度 (Kinetics) および end point を 測定した。

2. 測定項目 反応速度は反応開始 1 分後から 35 秒間に64点を測定し，そ の前後各32点の吸光度の差をRecorder による直線性の検討および平均 $\Delta \mathrm{E}$ を digital 表示により求めた. end point は任意の時間における吸光度を digital 表示で求めた. Kinetics や end point の Unit 值は今回は用いなかったが， ある係数を乗ずることができるため測 定項目による定数をあらかじめ求めて おけば unit 表示をすることができ る. 测光装置は 2 波長測光法であるた め $\lambda_{1} 450 \mathrm{~nm} ， \lambda_{2} 415 \mathrm{~nm}$ を用いた。 この 2 波長についてはあらかじめ S2251および反応生成物である p-Nitroaniline の吸収曲線を求め, 今回の測 定目的に合致することを確認してい る。

\section{II. 成績および考按}

\section{Plasmin $\subset \mathbf{S}-2251$}

S-2251濃度， 0.5，1，2，3mM/l の 各溶液 $0.1 \mathrm{~m} l$ （基質 $0.05 ， 0.1 ， 0.2$, $0.3 \mu \mathrm{M}$ ) 量と一定量の Plasmin (Kabi 社） $0.1 C U$ とを反応させ時間的経過 を追って Kinetics と end point を測定した結 果, end point は基質量と比例し時間経過と之 あに漸増する放物線状の反応曲線を示し， Kinetics では最初の 1 分で基質量に比例しかつ 最も高い值を示し以後時間経過とともに減少す る減衰曲線状の反応曲経を示した。

Lineweaber plot による $\mathrm{K}_{\mathrm{m}}$ 值は $7.6 \times 10^{-4}$ $\mathrm{mM}$ であった．基質量の選定は反応曲線よりで きる限り少量を選び， 基質量としては $0.1 \mu \mathrm{M}$ を用いるとととした。 $0.1 \mu \mathrm{M}$ 基質量における Plasmin 量との関係は Plasmin $0 \sim 0.25 \mathrm{CU}$ の 範囲で end point $\left(10^{\prime}\right)$ および Kinetics の測 定值は直線関係を示した(図 1)，各種 Plasmin 量におけるフィブリン平板法と C-Sub., Lysis time と C-Sub. の測定值の相関性を求めたが,

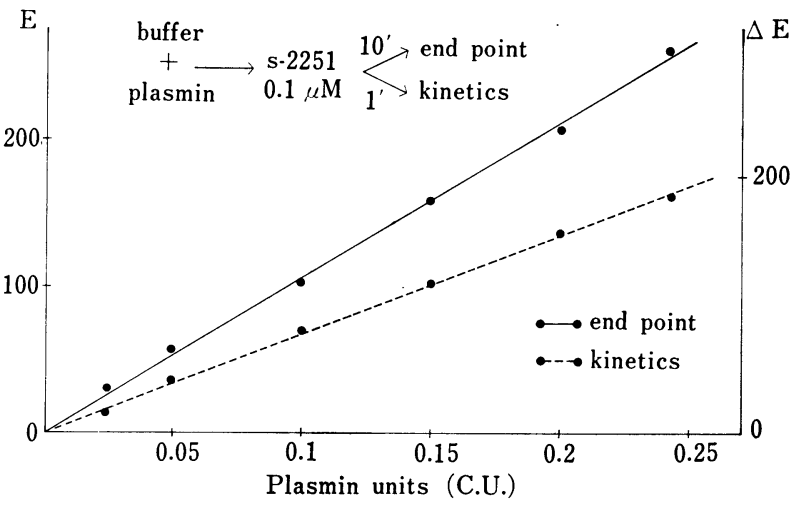

Fig. 1 Calibration curve of plasmin. Plasmin (from $0.025 \mathrm{CU}$-to $0.25 \mathrm{CU}$ ) were incubated with $0.1 \mathrm{ml}$ of $1 \mathrm{mM}$ chromogenic substrate, S-2251, and kinetics $(\Delta \mathrm{E})$ at $1 \mathrm{~min}$. and end point (E) at $10 \mathrm{~min}$. were measured.

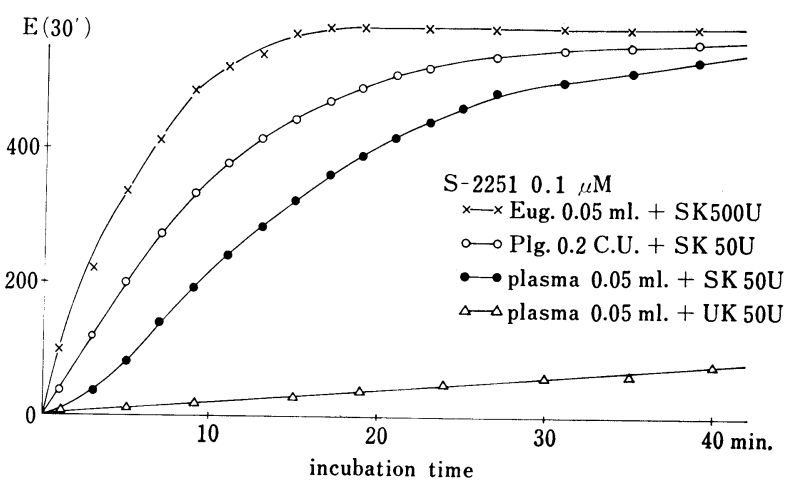

Fig. 2 Reaction curve of SK-plasminogen, SK-euglobulin, SK-plasma and UK-plasma with chromogenic substrate.

いずれあ直線性は示さず Semi-log グラフで直 線となった。

\section{Plasminogen-SK, UK ¿ S-2251}

精製した人 Plasminogen $(0.2 \mathrm{CU})$ を $\mathrm{SK} お$ よび UK で活性化し S-2251 との反応を調査 した. 同 unit の SK と UK による Kinetics は SK で初期により高い值が得られ UK では 時間的経過とと屯に漸増，その後減少する山形 の曲線を示したことから SK に比し UK の Plg. 活性化速度が遅いとみられた. Plg.-SK の 反応は SK 量に比例し Kinetics の值は増大 し，ことに 1 分以内に maximum に達してい るととが明らかとなった。また，SK 量による Kinetics の変化は end point より 比較的広範 囲であり0〜750Uまで変化がみられ Kinetics の 
Table 1 Specific properties of chromogena substrate, S-2251, with plasmin, SK-, UK-activated plasma and inhibitors.

\begin{tabular}{|c|c|c|c|}
\hline \multirow[t]{3}{*}{ Substrate } & Enzyme (inhibitor) & Kinetics & end point \\
\hline & Plasmin & $0 \sim 0.2 \mathrm{C} \mathrm{U}$ & $0 \sim 0.25 \mathrm{C} \mathrm{U}$ \\
\hline & Plg. $(0.2 \mathrm{CU})+\mathrm{SK}$ & $0 \sim 750 \mathrm{U}$ & $0 \sim 50 \mathrm{U}$ \\
\hline S-2251 & Plg. + SK (500U) & $0 \sim 0.3 \mathrm{C} \mathrm{U}$ & $0 \sim 0.2 \mathrm{C} \mathrm{U}{ }^{*}$ \\
\hline \multirow[t]{5}{*}{$1 \mathrm{mM} 0.1 \mathrm{ml}$} & Plg. $(0.2 \mathrm{CU})+\mathrm{UK}$ & $0 \sim 20 \mathrm{U}$ & $0 \sim 20 \mathrm{U}$ \\
\hline & Plasma + SK (500U) & $0 \sim 0.05 \mathrm{ml}$ & $0 \sim 0.04 \mathrm{ml}$ \\
\hline & Pl. $(0.1 \mathrm{CU})+\mathrm{t}-\mathrm{AMCHA}$ & $1 \mathrm{mg}<$ & $1 \mathrm{mg}<$ \\
\hline & Pl. (0.1CU) + trasylol & $0 \sim 5 \mathrm{U}^{*}$ & $0 \sim 3 U$ \\
\hline & Pl. (0.1CU) + plasma & $0 \sim 0.02 \mathrm{ml}^{*}$ & $0 \sim 0.006 \mathrm{ml}$ \\
\hline
\end{tabular}

* indicate none linear relationship.

值は単に生成 Plasmin 量を示すばかりでなく 活性化速度も示していた. UK の活性化の場合 は比較的長い反応時間による end point の測定 が有意であった。SK (500U) 一定量における $\mathrm{Plg}$, 量の測定範囲 $(0 \sim 0.3 \mathrm{CU})$ で直線性を示 した.

\section{Piasma-SK ¿ S-2251}

Plasma を SK で活性化し S-2251 との反応 を調べた結果 Plasmin や Plg. +SK と同様な 反応曲線を示し, SK 量や Plasma 量に比例し て Kinetics および end point 值に変化がみら れた. 図 2 は Plg., Eug. や Plasma を試料之 して SK および UK で活性化した反応曲線で ある.とのととから Plasma-SK により Plasmin 測定が可能であると判断された. SK 500U， S-2251 $0.1 \mu \mathrm{M}$ における Plasma 量の測定範囲 は Kinetics で $0 \sim 0.075 \mathrm{~m} l$ で直線性を示し, 試料 $0.05 \mathrm{~m} l$ で測定可能であった. Plasma 中 の Fibg. 量による影響は Plasmin-S-2251 の 反応系に $0 \sim 1,000 \mathrm{mg} / \mathrm{d} l$ の人 Fibg. を添加し てあ特に著しい影響はなく, 最あ変化のあった Kinetics で屯高濃度でわずか数\%の減少がみら れたのみである。

また, Plasma の anti-plasmin 効果, t-AM CHA, Trasylol の anti-plasmin 効果も測定で あるととを確めた. anti-plasmin 効果は end point により直線関係が求められた。調查の結 果をまとめたものが表 1 である.

これまで S-2251 について Blombäck5), Kosow $^{6)}$ らの研究はあるが本実験結果より $\mathrm{Pla}$ - sma の Plamin 作用が自動分析化可能であるこ とが明らかとなった。また Plasma の antiplasmin 作用についても Teger-Nilsson ${ }^{7}$, $\mathrm{Edy}^{8)}$ らの報告のごとく測定可能であり，本実 験からあ自動分析化をするととができるととが 明らかとなった。

\section{結語}

酵素反応速度自動分析機（日立 703 型）を用 いて, Chromogenic Substrate S-2251 と Plasmin, SK-plasminogen, SK-euglobulin, SKplasma との反応を rate assay (Kinetics), end point の両面より調査した. とれらの酵素的分 析から少量の基質 $(0.1 \mu \mathrm{M})$ であっても $\mathrm{SK}$ (500U) で活性化された Plasma $(0.05 \mathrm{~m} l)$ の 線溶活性は Kinetics を測定するととにより， anti-plasmin は end point を測定するととによ り自動分析化できる見通しがついた。

\section{文献}

1) 椙江 勇, 他：ELT の新しい写真判定式測定 装置の開発. 名市大医誌, $20 ; 357 \sim 364,1969$.

2) 小塩昌洋: ELT の意義と測定法の検討. 名市 大医誌, 20；673 690, 1970.

3）菱川要子, 他：人おょび牛の Plasminogen free fibrin plate の作製と検討. 愛知医大誌, 1; 132 143, 1973.

4) 菱川要子, 他: Plasminogen free fibrin plate を用いた線溶因子の指数について. 日生理誌, $39 ; 1 \sim 11,1977$. 
5) Svendson, L.: Synthetic chromogenic substrate for determination of trypsin, thrombin and thrombin-like enzymes. Thrombosis Res., 1; 267 278, 1972.

6) Kosow, D. P.: Kinetic mechanism of the activation of human plasminogen by SK. Biochem., 14; 4459 4464, 1975.

7) Teger-Nilsson, A.C.: Determination of new rapid plasmin inhibitor in human blood by means of a plasmin specific tripeotide substrate. Scand. J. Clin. Lab. Invest. to be published.

8) Edy, J. et al.: Inhibition of plasmin by normal and anti-plasmin-depleted human plasma. Throm. Res., 8; 513 524, 1976. 